\title{
Legal Protection Against Violations of the European Convention on Human Rights: Improving (Co-)operation of Strasbourg and Domestic Institutions
}

\author{
Tom Barkhuysen \& Michiel L. van Emmerik*
}

Keywords: human rights; ECHR; remedies; compensation.

\begin{abstract}
This contribution deals with legal protection against violations of the European Convention on Human Rights at both the national as well as the international level. The conclusion is that the practice of the European Court of Human Rights is inadequate and that the protection in the Netherlands could be better. Several recommendations are made in order to improve the co-operation between Strasbourg and domestic institutions in the field of the protection of human rights.
\end{abstract}

\section{INTRODUCTION}

The Eleventh Protocol to the European Convention on Human Rights (ECHR), which became effective on 1 November 1998, aims primarily at implementing (technical) changes in the Strasbourg supervisory system. It has been extensively commented on. ${ }^{1}$ It may, nevertheless, be doubted whether citizens benefit sufficiently from these changes should their legal protection be at stake due to a violation of the Convention. In our opinion, however, gathering a new Court in a new setting should be ample reason to improve this legal protection. Such improvements should be made both at the domestic level - as an example we will focus on the Dutch legal order - and the international (Strasbourg) level. In the sections 2 and 3 of this contribution, some recommendations are offered in this regard. Obviously, the system will only operate adequately when both levels co-

* Dr. T. Barkhuysen was associated with the Department of Constitutional and Administrative Law and the E.M. Meijers Institute of Leiden University. He is now attorney-at-law in Amsterdam. Dr. M.L. van Emmerik is associated with the Department of Public Law and the F.M. van Asbeck Centre for Human Rights Studies of Leiden University, currently working at the Ministry of the Interior, The Hague. English translation by L.T.M. Willems LL.M (Maastricht University).

1. See, e.g., H.G. Schermers, The Eleventh Protocol to the European Convention on Human Rights, 19 European Law Review 367-384 (1994); A. Drzemczewski \& J. Meyer-Ladewig, Principal characteristics of the new ECHR control mechanism as established by Protocol No. 11, signed on 11 May 1994, 15 Human Rights Law Journal 81-86 (1994). See also 21 NJCM-Bulletin $811-876$ (1997) containing several contributions on the Eleventh Protocol and the text of the new ECHR. After the Eleventh Protocol took effect, the numbering of the Convention articles partly changed. 
operate; section 4 deals with this co-operation. Finally, some conclusions will be drawn in section 5 of this article. ${ }^{2}$

\section{STRASBOURG: INADEQUATE}

\subsection{The state of affairs}

As regards effective legal protection afforded to applicants, the Strasbourg procedure is open to rather severe criticism - even with the incorporation of the Eleventh Protocol. It seems the supervisory institutions (continue to) grapple with reconciling both functions of the Strasbourg procedure. On the one hand, it is the Court's task to safeguard the implementation of treaty obligations in general, that is, separate from individual cases, using such cases only as an inducement to action (recours objectif). ${ }^{3}$ On the other hand, it is to offer legal protection to the individual involved in the procedure (recours subjectif).

Effective protection of human rights first of all requires the availability to an individual of an accessible, fast and professional procedure. ${ }^{4}$ The Strasbourg supervisory procedure does not comply completely with these criteria. It is relatively inaccessible, rather slow and burdensome. Furthermore, specific expertise on domestic law is often limited in Strasbourg, because attention has to be distributed among many domestic systems. In contrast, domestic institutions are in direct and continuous contact with important social forces within the member states. The European Court of Human Rights (Court or ECrtHR) also acknowledges that to pass judgment in a given case, domestic institutions are often in a superior position as compared to the Court. ${ }^{5}$ Furthermore, the Strasbourg institutions are far removed from the applicants. Added to this is the fact not everyone can afford the time and money to go to Strasbourg.

A second requirement of crucial importance to any procedure for the effective protection of human rights is that actual redress be guaranteed in case a fundamental right has been violated. The Strasbourg procedure cannot sufficiently

2. This article is based on our doctoral theses. They deal respectively with the right to effective domestic legal protection against human rights violations (Art. 13 ECHR) and with compensation for such violations (Art. 41 - the former Art. 50 - ECHR). See T. Barkhuysen, Artikel 13 EVRM: effectieve nationale rechtsbescherming bij schending van mensenrechten [Article 13 ECHR: Effective National Legal Protection in Case of Human Rights Violations] (1998) and M.L. van Emmerik, Schadevergoeding bij schending van mensenrechten, De rechtspraktijk onder het EVRM vergeleken met die in Nederland [Compensation for Human Rights Violations. Comparing the Legal Practice of the ECHR with Dutch Legal Practice] (1997)

3. See Art.19 ECHR.

4. See, e.g., A.J.P. Tammes, The Obligation to Provide Local Remedies, in M. Nolte et al. (Eds.), Volkenrechtelijke opstellen aangeboden aan G.J.H. van der Molen 152-168 (1962).

5. E.g., Handyside $v$. The United Kingdom, ECrtHR 7 December 1976 (Ser. A), Vol. 24, para. 48. See A.W. Heringa, Constitutionele partners [Constitutional Partners] (1996). 
meet this requirement. This is because judgments of the Court do not automatically nullify actions of contracting states that constitute violations of the Convention. In case a state does not honour a positive obligation deriving from the Convention, a Strasbourg judgment does not automatically provide an applicant with a claim to the state's (belated) action. The judgment has a declaratory character only: it merely contains a binding statement of a violation. ${ }^{6}$ States are obliged to provide redress, but it is left to their discretion how to honour this obligation. ${ }^{7}$ The Court lacks the authority to declare legislation or measures conflicting with the Convention void, nor can it review irrevocable verdicts of domestic courts. The Court is also not authorised to order the relevant contracting state to act. The Committee of Ministers however supervises the enforcement of Strasbourg judgments. ${ }^{8}$ Still, a complaint frequently heard is that a Strasbourg 'victory' brings the applicant little or no gain. In many contracting states, including the Netherlands, applicants have few or no options to claim redress based on a judgment of the Court. ${ }^{9}$ So far, case-law has not established whether an individual can complain in Strasbourg of a violation of Article 46 paragraph 1 ECHR (the obligation of a state to conform to judgments of the Court) when a contracting state does not implement a judgment. ${ }^{10}$ Nonetheless, based on Article 41 ECHR the Court has the authority to award the victim "just satisfaction." Indeed, research into the practice of the Court concerning Article 41 ECHR shows, on the one hand, that it liberally interprets this authority and considers itself competent to award equitable satisfaction as soon as the liable state refuses compensation claimed by an applicant. By doing so, it is not duly impressed by the condition contained in the article, that compensation can only be awarded when the domestic law of a contracting state only provides for partial

6. See Arts. 44-46 ECHR.

7. Marckx v. Belgium, ECrtHR 13 June 1979 (Ser. A), Vol. 31, para. 58.

8. Art. 46 (2) ECHR.

9. See T. Barkhuysen \& M.L. van Emmerik, Betere tenuitvoerlegging van Straatsburgse uitspraken in de Nederlandse rechtsorde: zaak heropenen of schadeclaim tegen de staat [Better Execution of the Strasbourg Decisions in the Dutch Legal Order: Re-open a Case, or Bring a Claim for Damages Against the State], 21 NJCM-Bulletin 987-1051(1996).

10. Olsson (no. 2) v. Sweden., ECrtHR 27 November 1992, (Ser. A), Vol. 250. See S.K. Martens, Individual Complaints Under Article 53 of the European Convention on Human Rights, in R. Lawson \& M. de Blois (Eds.), The Dynamics of the Protection of Human Rights in Europe, Essays in Honour of Henry G. Schermers 253-292 (1994).

11. With the Eleventh Protocol the wording of Art. 50 - without aiming at material change - has become more concise and is to be found in Art. 41: "If the Court finds that there has been a violation of the Convention or the protocols thereto, and if the internal law of the High Contracting Party concerned allows only partial reparation to be made, the Court shall, if necessary, afford just satisfaction to the injured party." See on Art. 41, e.g., Montserrat Enrich Mas, Right to Compensation Under Article 50, in R.St.J. Macdonald et al. (Eds.), The European System for the Protection of Human Rights 775-790 (1993); H.C. Krüger, Reflections on Some Aspects of Just Satisfaction Under the European Convention on Human Rights, in V. Berger et al. (Eds.), Liber amicorum M.-A. Eissen, 255-269 (1995); and J.L. Sharpe, Article 50, in L.E. Petitti et al. (Eds.), La Convention Européenne des Droits de l'Homme, Commentaire article par article, 809-842 (1995). 
redress of the consequences of a treaty violation. On the other hand, the Court often awards no compensation at all. It contents itself regularly, without any motivation, with pronouncing that the mere finding of a violation of the Convention constitutes sufficient satisfaction for non-material damage incurred. Furthermore, claims concerning material damage are dismissed on the ground the Court cannot speculate on the outcome of the domestic procedure should the requirements of the Convention have been fulfilled. ${ }^{12}$ In other words, the Court has difficulties in establishing a causal link between a treaty violation and damage. Added to the fact that Article 41 ECHR provides the Court with inadequate authority, the present practice on compensation - insufficiently safeguarded and inconsistent - emphasises the need for domestic means of redress after a Strasbourg condemnation.

Considering all this, it is possible to conclude that the Strasbourg procedure insufficiently guarantees actual redress after the violation of a fundamental right. Also, the long duration of a Strasbourg procedure detracts from this 'healing' power. It is not to be expected that these procedural shortcomings will be corrected in the near future, not even with the Eleventh Protocol in force. This Protocol does not provide for substantial adjustments of treaty provisions concerning the consequences of established treaty violations. Statistics published by the Registrar of the Court, show that the Protocol so far has not lead to a faster settlement of complaints. On the contrary, the workload of the Court has continued to rise sharply. ${ }^{13}$ If any improvements in this respect would be possible, they would probably be offset by the expected increase in the number of complaints after the accession of a lot of new Contracting States. After the recent Georgian ratification of the ECHR there are 41 Contracting States and about 700 million potential applicants. The Eleventh Protocol has abolished the Commission, which up until its abolishment acted as a sort of 'filter'. As a consequence, some authors fear the Court will be inundated, causing complaints about relatively minor violations to suffer. Increasingly, the Court will have to prioritise.

\subsection{Suggestions for improvement}

The Court should attempt to cope with the shortcomings in the Strasbourg legal protection described above. We are aware, however, of the challenges posed by the present powers of the Court and the available (financial) means. Consequently, in our opinion, an extension of these powers and a higher budget should be given to the Court where necessary. More financial means might contribute to the speed and accessibility of the Strasbourg procedure, especially by increasing

12. Comparable conclusions concerning the practice of the Court on Art. 41 ECHR are drawn by A.R. Mowbray, The European Court of Human Rights' Approach to Just Satisfaction, 4 (Winter), Public Law 647-658 (1997).

13. See Press Release, 21 June 1999, no. 349. 
staff volume. In this way also, more specific expertise on the differing domestic legal systems could be incorporated. Within the existing setting at least, the following improvements in the Strasbourg legal protection might be realised.

First, the Court should streamline its decisions on compensation, based on Article 41 ECHR. The Court should thoroughly motivate these judgments, especially when it rejects a claim to compensation, or confines itself to declaring the finding of a treaty violation as sufficient just satisfaction for the purposes of Article 41 ECHR. If the Court would establish a certain standard of compensation for non-material harm, indexed to the standard of living in the relevant Contracting State, this would contribute to equality before the law and to legal security. For instance, the Court could determine set amounts of money for every day of detention in violation of Article 5 ECHR, or for the violation of the reasonable time requirement laid down in Article 6 ECHR. While on the one hand, it should be admitted that such standardisation is arbitrary, on the other hand, it may help prevent arbitrariness. Furthermore, the Court should be able to take into account the special circumstances in a particular case and to deviate from the standards set. This might result in awarding a higher amount, for instance, in the case of depriving a psychiatric patient of his liberty and administering forced medication in violation of Article 5 ECHR, or a lower amount in the case of a minor procedural omission. In case the harm is very slight, the Court could possibly confine itself to considering the finding of a violation sufficient satisfaction, albeit on the condition that this decision is thoroughly motivated.

Second, the Court could, where appropriate, make suggestions as to the reparations to be made by the State found liable. For instance, in the case of an expropriation in violation of Article 1 of the First Protocol, the Court might recommend the property to be returned to remedy the violation. This way, restitutio in integrum may be approximated and future violations be prevented. The practice under the American Convention on Human Rights may serve as an example (Article 63 ACHR). ${ }^{14}$

Last, the Strasbourg legal protection might gain in impact by requesting states more frequently to arrange for interim measures of protection for the duration of the Strasbourg procedure (the present 'Rule 39' procedure) - and not only in cases about aliens. In our opinion, further - comparative - research is needed in this area, especially concerning the option to make these requests binding.

14. See, e.g., B. Fontana, Damage Awards for Human Rights Violations in the European and InterAmerican Courts of Human Rights, 31 Santa Clara Law Review 1127-1169 (1991). 


\section{THE NETHERLANDS: COULD BE BETTER}

\subsection{The state of affairs}

Article 13 ECHR lists the requirements domestic legal protection should meet in cases of violations of human rights. States are obliged to provide for domestic legal remedies in case of a breach of the Convention. ${ }^{15}$ This article awards individuals a right to an effective domestic legal remedy against (alleged) violations of human rights as contained in the Convention. Article 13 in this way obliges states to provide for effective domestic legal protection and offers the Strasbourg and domestic institutions the means to supervise the implementation of this obligation. For Article 13 ECHR to be applicable it is not required - unlike the wording of the article suggests - that a violation has been found of the material right invoked simultaneously. The Court determined this in $1978 .{ }^{16}$ More recently, case-law specified that an 'arguable claim' to a violation of a right is necessary for the applicability of Article 13 ECHR. ${ }^{17}$

Since 1978, the case-law of Court and Commission on Article 13 shows a substantial increase in the number of requirements domestic legal protection is to meet. ${ }^{18}$ Roughly speaking, these amount to the following. A procedure should be available before a national authority so as to investigate a complaint of a breach of Convention rights. In this procedure either the Convention rights themselves, or materially comparable national standards should be applicable. If the complaint is found to be valid, the national authority should have the power to reach a binding decision on full redress (restitutio in integrum). Should this no longer be an option, it should be possible to award compensation. This national authority does not necessarily need to be a judicial institution. In order to meet the requirements of effectivity of Article 13, it should be more or less comparable to a judicial institution where its authority and procedural guarantees (e.g. independence and impartiality) are concerned. Subsequently, this article obliges the relevant national authorities in cases of (alleged) violations of

15. Art. 13 ECHR: "Everyone whose rights and freedoms as set forth in this Convention are violated shall have an effective remedy before a national authority notwithstanding that the violation has been committed by persons acting in an official capacity." On Art. 13 ECHR see also A. Drzemczewski \& C. Giakoumopoulos, Article 13, in L.E. Pettiti et al. (Eds.), supra note 11, at 455-474; G.H. Thune, The Right to an Effective Remedy in Domestic Law: Article 13 of the European Convention on Human Rights, in D. Gomien (Ed.), Broadening the Frontiers of Human Rights (Essays in Honour of Asbjørn Eide) 79-95 (1993).

16. Klass et al. v. Germany, ECrtHR 6 September 1978, (Ser. A), Vol. 28, para. 62 et seq.

17. Silver et al. $v$. The United Kingdom, ECrtHR 25 March 1983, (Ser. A), Vol. 61, para. 113.

18. See, e.g., Swedish Engine Drivers' Union v. Sweden, ECrtHR 6 February 1976, (Ser. A), Vol. 20; Klass et al. $v$. Germany, ECrtHR 6 September 1978, (Ser. A), Vol. 28; Silver et al. v. The United Kingdom, ECrtHR 25 March 1983, (Ser. A), Vol. 61; Leander v. Sweden, ECrtHR 26 March 1987, (Ser. A), Vol. 116; Soering $v$. The United Kingdom, ECrtHR 7 July 1989, (Ser. A), Vol. 161. 
human rights actually to exercise the required powers mentioned above, and in doing so to provide actual legal protection in a specific case.

However, in our opinion the final verdict on the Strasbourg case-law on Article 13 is not a positive one. The requirements of the legal protection offered could be extended. Also, the scope of Article 13 should be widened to encompass primary legislation (Acts of Parliament). Furthermore, limitations on the right to effective legal protection, for instance, when national security is at issue, should be less acceptable. Finally, the Strasbourg institutions should, more consistently than up till now, supervise the implementation of the obligations under Article 13. They should definitely not avoid the application of this article by pointing to the investigation of other Convention rights invoked.

Dutch legal protection meets the requirements described above reasonably well. One important reason for this is the availability in the Netherlands of a procedure before a judicial institution for, in principle, all cases of (alleged) violations of human rights. When there is or has been no special judicial procedure available, the civil courts can in principle hear a case on tort. In the Netherlands the civil courts thus, so to speak, close the 'loopholes' in the legal protection. Furthermore, Dutch judges usually have adequate authority to deal with a complaint about a violation of a human right. Of special importance is the incorporation of the Convention in the Dutch legal order, the precedence of its stipulations over conflicting national norms (including Acts of Parliament), and the option for Dutch citizens directly to invoke most stipulations of the Convention in a judicial procedure (Articles 93 and 94 of the Constitution). ${ }^{19}$ Another contribution to the effectivity of the Dutch protection of human rights, is the frequent willingness of Dutch judges to take into account the judgments of the Strasbourg Court, even where the addressees were other States. Lastly, Dutch judicial institutions and counsel, generally speaking, have a reasonable level of expertise on the Convention and the most important Strasbourg case-law. These days, the Convention and Strasbourg case-law form part of the education of judges and counsel.

\subsection{Suggestions for improvement}

All the same, there is room for improvement of the Dutch legal protection against violations of human rights. There are cases in which a Dutch judge will find a breach of the Convention, but subsequently do no more than pronounce himself incompetent on the question of reparation, asserting that this question

19. See P. van Dijk, De houding van de Hoge Raad jegens verdragen inzake de rechten van de mens [The Attitude of the Supreme Court towards Human Rights Treaties], in B. Baardman et al. (Ed.), De plaats van de Hoge Raad in het huidige staatsbestel (1988). 
falls within the competence of the legislature. ${ }^{20}$ Because of this 'abstinence', the Article 13 obligation to provide an effective remedy in a specific case after a Convention violation has been established, is not met. In this way, the applicant, who has been found to be in the right, is sent home empty-handed and remains, unjustly, 'the third dog in the game of skittles'. Furthermore, the legal protection offered by the civil courts is sometimes less than perfect, because for the time being the Supreme Court assumes only an extremely limited liability on the grounds of wrongful administration of justice. ${ }^{21}$ In our opinion, this liability should be extended, because the judiciary too might violate the Convention by its actions (judgments), for example, in connection with the requirements of Article 6 ECHR. In cases like these, there should also be an effective remedy. Furthermore, more liberal compensation for non-material harm, caused by violations of human rights, should be awarded (on the basis of Article 6:106 juncto 6:162 Civil Code). Dutch case-law in this respect needs to catch up with that of Strasbourg, especially in cases of violations of procedural rights, like the exceeding of the reasonable time-limits.

\section{STRASBOURG - THE NETHERLANDS: IMPROVED CO-OPERATION}

The preceding paragraphs dealt with the legal protection offered by the Strasbourg and the domestic (Dutch) institutions. Suggestions have been made for the improvement of the legal protection at both levels separately. As stated in the introduction, the system of protection of human rights under the Convention can only operate effectively on the basis of smooth co-operation between the Strasbourg and domestic (Dutch) institutions. The following offers some remarks on this co-operation.

\subsection{Emphasis on domestic legal protection}

Applicants should not have to appeal to Strasbourg. Naturally, in order to achieve this, the prevention of violations should be put first (for instance, by examining domestic legislation against the Convention before it is put into effect). If a violation does occur, this should in our opinion be 'repaired' by a domestic institution. In other words, the emphasis in legal protection should be on the domestic level. This would still be valid even if the Strasbourg procedure for redress were to be improved.

The preceding paragraphs have shown that to provide effective legal protection at higher speed and of a better quality, domestic institutions are, in princi-

20. See for instance Hoge Raad (Supreme Court) 5 September 1997, 22 NJCM-Bulletin 149-155 (1998), with note by C. Forder (adoption by two lesbian mothers).

21. Hoge Raad 3 December 1971, NJ 1972, 137 with note by G.J. Scholten. 
ple, better equipped than international ones. For applicants, a domestic procedure is usually preferable.

Furthermore, the availability of effective domestic remedies is of importance for the (continued) operation of the Strasbourg supervisory system.

To begin with, domestic remedies have an important 'filter function'. Many complaints can be dealt with at a national level, Strasbourg thus not being unduly burdened. The Strasbourg system is not geared to dealing with complaints as a court of first instance. Also, from the point of view of state sovereignty, it would be unreasonable to require a state to justify itself directly in Strasbourg before its own institutions would have had an opportunity to judge the complaint - an argument which constitutes the basis for Article 35, paragraph 1 ECHR, entailing the obligation to exhaust domestic remedies before complaining in Strasbourg. This filter function of the domestic remedies only increases in importance with the increase in the number of Contracting States to the ECHR. In spite of the efforts of the new - mostly Eastern European - Contracting States to model their legislation after the requirements of the ECHR, an increase in the number of complaints is to be expected. As a consequence, the Strasbourg system will be in danger of collapse. If states would comply completely with the preferably more broadly interpreted - obligation of Article 13 in combination with the obligation for individuals ex Article 35, paragraph 1 ECHR to utilise the available effective domestic remedies, it would be feasible to realise a (further) 'decentralisation' of the legal protection from the international to the national level.

Furthermore, for those complaints which would reach Strasbourg, the task of the Strasbourg institutions in judging them would be alleviated by the fact that a domestic institution would have established the facts and have dealt with the arguments of both the applicant and the state. In the context of a given case, something of a dialogue could take place between the domestic institution examining the complaint and Strasbourg. The preparatory efforts of domestic institutions only increase in importance now the Eleventh Protocol has abolished the Commission. The Commission had an important role in preparing cases for the Court.

Even though this is not stated explicitly in the Convention, it is clear the Strasbourg supervisory mechanism is based on the principle of subsidiarity. ${ }^{22}$ The Strasbourg supervision is only intended to supplement the domestic remedies. ${ }^{23}$ This subsidiarity concerns primarily the procedural relation between national and international supervising institutions (the rule of exhaustion). None-

22. This can implicitly be derived from Arts. 1, 13, 35, 41, 52 and 53 ECHR.

23. See Belgian Linguistic cases, ECrtHR 23 July 1968, (Ser. A), Vol. 6, para. 10; Handyside $v$. The United Kingdom, ECrtHR 7 December 1976, (Ser. A), Vol. 24, para. 48. More recently, with the literal use of the concept 'subsidiarity', United Communist Party of Turkey v. Turkey, ECrtHR 30 January 1998, RJD 1998, para. 28. 
theless, it has material implications also. These are first and foremost concerned with the limits Strasbourg institutions are to heed when exercising their supervision. When reviewing the actions or failures to act by governmental institutions, Strasbourg allows national authorities a certain 'margin of appreciation' ${ }^{24}$ Furthermore, Strasbourg emphasises it is not a court of appeal. Implementing the obligations deriving from Article 13 ECHR contributes to putting into practice the principle of subsidiarity. ${ }^{25}$ If States would show an increasing willingness to do so, the Strasbourg institutions can be expected to be increasingly reticent in their review. In such circumstances they can focus on guiding and assisting domestic institutions in their supervision of the compliance with treaty obligations by states.

\subsection{Strasbourg as adequately equipped 'catcher'}

If a case eventually does arrive in Strasbourg and a violation of the Convention is found, maximum redress should be offered there. The applicant has invested time and money to acquire a Strasbourg decision. Hence, it would not be correct to make him return to a domestic procedure empty-handed if he is found to be in the right. In some cases, however, Strasbourg is not adequately equipped with powers or other means to provide for redress and is forced - under reservation of a decision on Article 41 ECHR - to refer the case to the national level.

Such a referral seems appropriate to us only in two situations. The first would be if restitutio in integrum can be awarded at the national level, for instance by reopening a domestic procedure, or by changing an administrative decision found to violate the Convention. This could lead to quashing a judicial judgment in a concluded case, or reaching a new one in conformity with the Convention, something for which Strasbourg lacks authority. ${ }^{26}$ Second, referral would be appropriate when the Court is (factually) incapable of adequately determining the extent of the harm, while there are strong indications the relevant domestic institution might be capable of this.

Of course, after referral, the applicant having been found to be in the right, should not have to wait for years after his 'Strasbourg victory' to be awarded domestic redress, or a decision on the extent of the material damage.

In the Clooth case, for instance, the decision on Article 41 ECHR was delayed for no less than six years. In the 1991 judgment on the merits, the Court

24. See H.C. Yourow, The Margin of Appreciation Doctrine in the Dynamics of European Human Rights Jurisprudence (1996).

25. See, e.g., H. Petzold, The Convention and the Principle of Subsidiarity, in R.St.J. Macdonald et al. (Eds.), The European System for the Protection of Human Rights, 41-62 (1993); Garcia Ruiz v. Spain, ECrtHR 21 January 1999, RJD 1999, para. 28.

26. See, e.g., Windisch v. Austria, ECrtHR 27 September 1990, (Ser. A), Vol. 186 and Windisch v. Austria (Article 50), ECrtHR 28 June 1993, (Ser. A), Vol. 255-D (reopening of a national criminal procedure after the Court found a violation of Art. 6 ECHR, caused by the use of anonymous witnesses). 
found a violation of Article 5, paragraph $3 \mathrm{ECHR}$ because of the duration of the provisional detention. ${ }^{27}$ The Court reserved the matter of Article 41 ECHR in view of the option to obtain compensation in Belgium on grounds of unlawful deprivation of liberty. At the national level, the Court of Appeal in Brussels, on 7 November 1997, awarded the applicant, Mr Clooth, a compensation of 125.000 Belgian Francs for non-material harm. Mr Clooth, however, was of the opinion that this domestic judgment only partly compensated him for the harm caused by the violation of Article 5 ECHR and he filed additional claims. Ruling on Article 41 ECHR, the Strasbourg Court stated on 5 March 1998, that the judgment of the Court of Appeal in Brussels, offered sufficient redress for the violation found on the merits, on the condition that this judgment was irrevocable. ${ }^{28}$

In our opinion, this case is an example that should not be followed: only after more than six years a decision - and not even an irrevocable one - was reached, leaving room for doubt as to whether the damage had been fully compensated. This case can hardly be described as effective protection of human rights. After referral for domestic redress the Court should set a time limit, for instance, one year. If within this year domestic redress has not been offered, the Court itself should deal with the claim concerning Article 41 ECHR.

In our view, the option of referral to a domestic institution offers no solace for non-material damage suffered by the applicant. This type of damage might just as well be dealt with by 'Strasbourg', according to the standards described in paragraph 2 of this contribution. In this way the applicant is spared a needlessly extended procedure before a domestic court. This would conform to the object and purpose of the Convention, which is to offer effective protection of human rights. ${ }^{29}$

\subsection{Mutual aid}

The Strasbourg and domestic institutions should also improve their mutual assistance in providing protection of human rights.

'Strasbourg' could provide support to the domestic institutions - apart from vigilant supervision of the availability of effective domestic remedies as required by Article $13 \mathrm{ECHR}$ - in the following ways. In the first place, we would like to draw renewed attention to an 'old', but still important suggestion. In our opinion it would be ideal if the Strasbourg Court, after the model of the European Court of Justice, would be given the authority to receive and answer preliminary questions from domestic institutions during the course of a domestic

27. Clooth $v$. Belgium, ECrtHR 12 December 1991, (Ser. A), Vol. 225.

28. Clooth $v$. Belgium (Article 50), ECrtHR 5 March 1998, RJD 1998, para. 14-16.

29. See Barberà, Messegué and Jabardo v. Spain (Article 50), ECrtHR 13 June 1994 (Ser. A), Vol. 285C, para. 17. 
through a better organisation of the inclusion of Strasbourg decisions into the decision-making by domestic institutions. This requires, among other things, the creation of an adequate system of information on the Convention and the verdicts of the Court for the benefit of the national courts, the legislature and the administration, as well as the consistent testing in abstracto of draft legislation against Convention rights. In this regard, in the future, the suggestions of the Court and the reports of the Secretary General may possibly be used.

\section{CONCLUSION}

Where the protection of Convention rights is at issue, the (co-)operation of Strasbourg and domestic institutions can still be vastly improved. Some of our suggestions with respect to the improvement of such co-operation are easily executed, others are not. But if the Strasbourg machinery is not to collapse, improved prevention of violations and greater emphasis on effective domestic legal protection is vital. To maintain the credibility of the ECHR supervisory system it is also absolutely essential that improvements are made concerning compensation in case of Convention violations. Again, the domestic institutions would play an important part. If citizens are to have faith in it, 'Strasbourg' must be able to offer them real results. 
procedure. In this way, significance and scope of Convention stipulations can be established early on, so as to spare the applicant the long road to Strasbourg. The execution of a Strasbourg judgment in a specific case could be further facilitated if the European Court in its judgments would clearly indicate why a violation has been found and which measures are required to implement the judgment (these suggestions are discussed in paragraph 2 of this contribution). In case any obscurities remain, according to the Rules of Procedure, the Court may be asked to interpret its own judgment. As far as we are concerned, the Court should apply this power more liberally. ${ }^{30}$ Quite separate from disputes before the Court, clear(er) Strasbourg judgments might assist domestic institutions in finding and redressing violations at the national level. This might also help prevent the occurrence of Convention violations. Furthermore, in order to prevent Convention violations, certain domestic institutions (including the legislature) should have a realistic chance to ask the Court's advice on whether, for instance, draft legislation is (in abstracto) compatible with Convention rights. This is probably not feasible in the short run. But at present the Secretary General of the Council of Europe could at any rate start utilising his authority, based on Article 52 ECHR, to request reports from Contracting States on the implementation of Convention obligations in their domestic system. This too might have a considerable preventive effect.

The other way around, domestic institutions might also be able to help 'Strasbourg'. Naturally first and foremost by showing an active attitude concerning (alleged) violations of the Convention. Domestic institutions should utilise all their potential powers thoroughly to investigate a complaint about a violation of human rights and, if necessary, offer redress. For us, this obviously includes the use of preliminary questions, as described above, as soon as this option becomes available. If things still go wrong and Strasbourg finds a violation, the Strasbourg judgment should be correctly executed at the national level. In our opinion, this necessitates creating the option of reopening domestic cases. ${ }^{31}$ After reopening a case, a new decision may be reached, taking into account the Strasbourg verdict (including possible suggestions). ${ }^{32}$ For those cases in which this revision offers no solution, there should be an option to obtain realistic compensation within a reasonable time. Apart from specific disputes, extended prevention of Convention violations might be attained, more in general,

30. In our opinion the Court takes a too restrictive stand in Allenet de Ribemont $v$. France, ECrtHR 7 August 1996, RJD 1996 and Hentrich $v$. France, ECrtHR 3 July 1997, RJD 1997.

31. Some Contracting States already offer this option. See for an inventory the study by the 'Committee of Experts for the improvement of procedures for the protection of Human Rights under the authority of the Steering Committee of Human Rights', Council of Europe, Strasbourg, January 1992, $13 \mathrm{Hu}$ man Rights Law Journal 71-78 (1992).

32. See on this subject extensively T. Barkhuysen, M.L. van Emmerik \& P.H.P.H.M.C. van Kempen (Eds.), The Execution of Strasbourg and Geneva Human Rights Decisions in the National Legal Order (1999). 